\title{
Sodium-Potassium Adenosine Triphosphatase Inhibitor RX108
}

National Cancer Institute

\section{Source}

National Cancer Institute. Sodium-Potassium Adenosine Triphosphatase Inhibitor RX108.

NCI Thesaurus. Code C156728.

A small-molecule, inhibitor of sodium-potassium adenosine triphosphatase $(\mathrm{Na}+/ \mathrm{K}+-$ AT Pase) with potential antineoplastic activity. Upon administration, RX108 inhibits the activity of the $\mathrm{Na}+/ \mathrm{K}+$-ATPase, which prevents the activation of various signal transduction pathways that play a key role in tumor proliferation. This may lead to cellcycle arrest, apoptosis, and autophagic cell death. $\mathrm{Na}+/ \mathrm{K}+-\mathrm{AT}$ Pase is overexpressed in certain tumor types and may serve as a scaffold for the assembly of multiple-protein signaling complexes that regulate cell proliferation and motility. In normal, healthy cells, the $\mathrm{Na}+/ \mathrm{K}+-\mathrm{AT}$ Pase controls transportation of $\mathrm{Na}+$ and $\mathrm{K}+$ across the cell membrane and is essential for electrochemical gradient maintenance, osmotic balance, and cellular $\mathrm{pH}$. 